\title{
SCIENTIFIC REPORTS

\section{Simultaneous Determination of Gross Alpha/Beta Activities in Groundwater for Ingestion Effective Dose and its Associated Public Health Risk Prevention}

\author{
Phan Long Ho ${ }^{1,2,4}$, Le Dinh Hung ${ }^{4}$, VuTuan Minh ${ }^{4}$, Dang Van Chinh ${ }^{4}$, Tran Thien Thanh $\mathbb{1}^{1,2,3^{*}}$ \& \\ Chau Van Tao ${ }^{1,2,3}$
}

This paper presents information on the gross alpha and gross beta activity concentrations of two hundred twenty-six ground water samples collected by gas flow proportional counters in southern Vietnam. The gross alpha results in the water samples ranged from 0.024 to $0.748 \mathrm{BqL}^{-1}$ with a mean of $0.183 \pm 0.034 \mathrm{~Bq} \mathrm{~L}^{-1}$, and the gross beta results in the water samples ranged from $0.027-0.632 \mathrm{~Bq} \mathrm{~L}^{-1}$ with a mean of $0.152 \pm 0.015 \mathrm{~Bq} \mathrm{~L}^{-1}$. The values obtained in this work were compared with those previously published for various regions or countries. Next, untreated and treated groundwater samples were analyzed to assess their influences on the treatment process. The results showed that there were differences in the minimum detection concentrations and the mean activity values between the untreated and treated groundwater samples (The $p$-value of the mean comparison tests is significant with $p<0.05$ ). In both sample groups, there was a strong positive correlation of the gross alpha versus the gross beta results $(r>0.6)$. This means that among the radionuclides, the major sources of beta radiation are uranium and thorium decay series radionuclides. Finally, the annual effective dose for adults ( $>17$ years) was calculated based on the assumption that major radionuclides have the highest effective dose conversion factors. In general, the results for $\mathrm{Pb}-210$, Ra-226, and Ra-228 were observed to be lower than the recommended reference values established by the World Health Organization and the International Atomic Energy Agency, except for the value of Po-210.

Water is the most important substance in our lives, and the management of water resources is a national and international problem. Water is an essential and basic human right and protecting the quality of water is also a component of effective health policy ${ }^{1-4}$. Water is considered to be a factor that can increase the exposure of humans to natural radiation ${ }^{5}$. The radioactivity present in groundwater may be mainly from the following radionuclides: nuclides in the U-238 and Th-232 decay series, K-40, cosmic rays, authorized discharges from nuclear facilities and other licensed facilities, fallout from nuclear weapon tests, and accidental releases of radionuclides ${ }^{4}$. The primary alpha-emitting radionuclides in the natural decay series are U-238 and Th-232 and its progenies U-234, Th-230, Ra-226, Po-210, and Th-228. In general, gross beta activity concentrations ${ }^{6-9}$ are primarily due to $\mathrm{K}-40, \mathrm{Ra}-228$, and $\mathrm{Pb}-210$.

There are several standards or regulations limiting concentrations of radionuclides in the water samples, which requires the ability to identify and quantify radionuclides utilizing different methods, such as alpha spectroscopy $^{10-13}$, gamma spectroscopy ${ }^{13-16}$, and liquid scintillation counting ${ }^{17,18}$. However, the process of identifying separation procedures for radionuclide concentrations in water samples is time consuming and expensive. Therefore, the simplest practical approach is to use a screening method based on the measurement of gross alpha and gross beta activity concentrations without regard to the identity of specific radionuclides ${ }^{2,3,9,19}$. This screening

${ }^{1}$ Department of Nuclear Physics, Faculty of Physics and Engineering Physics, University of Science, Ho Chi Minh City, Vietnam. ${ }^{2}$ Vietnam National University, Ho Chi Minh City, Vietnam. ${ }^{3}$ Nuclear Technique Laboratory, University of Science, Ho Chi Minh City, Vietnam. ${ }^{4}$ Institute of Public Health in Ho Chi Minh City, Ho Chi Minh City, Vietnam. *email: ttthanh@hcmus.edu.vn 
method is also the first step of radiological characterization in the field of radioecology, environmental monitoring, and industrial applications. Its major advantages are its low cost and simplicity ${ }^{9,20}$.

In this work, the gross alpha and gross beta activity concentrations of two hundred twenty-six groundwater samples in southern Vietnam were determined from untreated and treated samples. The annual effective doses of groundwater ingestion for the adult age group were evaluated and compared to the reference dose recommended for radionuclides in drinking water. To date, no study has been performed in this region on groundwater radioactivity.

\section{Materials and Methods}

Study area and water sampling. Southern Vietnam includes southeast and Mekong River delta regions ${ }^{21}$. The nation measures approximately $64,369 \mathrm{~km}^{2}$ and has a population of approximately 34.48 million, as of 2017 . The samples were collected by the partners of the Institute of Public Health in Ho Chi Minh City. In all 226 samples, 108 samples (labeled S1-S108) have untreated groundwater as the source with a mean total dissolved solids (TDS) content of $255 \pm 134 \mathrm{mg} \mathrm{L}^{-1}$, and the other samples (S109-S226) have treated groundwater as the source with a mean TDS content of $124 \pm 113 \mathrm{mg} \mathrm{L}^{-1}$. In which, the untreated sample was collected directly from drilling well and the treated sample was taken from the filtration system with technologies such as filter, ion exchange, reverse osmosis, etc. The samples were collected in 1-liter plastic containers, and then the samples were acidified with nitric acid $\left(\mathrm{HNO}_{3}\right)$ until reaching a $\mathrm{pH}$ level below 2 to avoid any biological activity and adsorption losses of radionuclides around the container walls and on solid surfaces.

Determination of gross alpha and beta activities by GFPC. The gross alpha and gross beta activity measurements, called the thin source deposit method, were performed as the first step in the radiological characterization of the water samples, and this method includes the standards ISO 10704:2009 for non-saline water $^{22}$. This procedure is accredited as ISO 17025:2017 by the Vietnam Bureau of Accreditation. For the gross alpha and gross beta analyses, $250 \mathrm{ml}$ of each groundwater sample was evaporated without boiling at $\leq 85^{\circ} \mathrm{C}$ (ensuring deposits with a surface density below $5 \mathrm{mg} \mathrm{cm}^{-2}$ ). The obtained residue was transferred to a stainless steel planchet ( 2 inch diameter and 1/8 inch depth). Each planchet was measured for gross alpha and gross beta activity during a $120 \mathrm{~min}$ interval per sample at the Institute of Public Health in Ho Chi Minh City using a low-background WPC-1050 (Protean Instruments Corporation). The detector type was a gas flow proportional counter (GFPC) with a mixture of $90 \%$ argon and $10 \%$ methane (P-10) and an automatic 50 sample transport. The operating high voltage of the detector was set at $1,515 \mathrm{~V}$. The background of each detector was determined by counting empty planchets for 3,600 min.

The detectors were calibrated for alpha and beta efficiencies using Am-241 (10.0 $\pm 0.1 \mathrm{~Bq})$ and Sr-90/Y-90 $(10.3 \pm 0.2 \mathrm{~Bq})$ standard solution sources, which were supplied by the Eckert \& Zeigler company. The gross alpha efficiency was $18.4 \pm 0.4 \%$, while the gross beta efficiency was $67.5 \pm 0.5 \%$, and the alpha-beta crosstalk correction factor $(\chi)$ was $32.1 \pm 1.0 \%$. The self-absorption curve of gross alpha activity concentration was made by adding the same Am-241 ( $3.53 \pm 0.05 \mathrm{~Bq})$ to seven tap water samples with different volumes of $0,100,200$, $400,600,800$, and $1000 \mathrm{~mL}$. The solutions were prepared with the same analyzed sample preparation procedure; their residues were deposited on a planchet and were determined to be in the range of $0-100 \mathrm{mg}$. Then, they were counted by WPC-1050, and the self-absorption curves were fitted to the exponential function $\mathrm{f}_{\mathrm{a} \alpha}=$ $0.9986 \times \exp (-0.0097 \times \mathrm{m})$, where $\mathrm{m}$ is the mass of the deposit $(\mathrm{mg})$.

The gross alpha and gross beta activity concentrations can be obtained as followed ${ }^{22}$ :

$$
\begin{gathered}
\mathrm{A}_{\alpha}\left(\mathrm{Bq} \mathrm{L}^{-1}\right)=\frac{\mathrm{r}_{\mathrm{g} \alpha}-\mathrm{r}_{0 \alpha}}{\mathrm{V} \times \varepsilon_{\alpha} \times \mathrm{f}_{\mathrm{a} \alpha}} \\
\mathrm{A}_{\beta}\left(\mathrm{Bq} \mathrm{L}^{-1}\right)=\frac{\mathrm{r}_{\mathrm{g} \beta}-\mathrm{r}_{0 \beta}-\chi\left(\mathrm{r}_{\mathrm{g} \alpha}-\mathrm{r}_{0 \alpha}\right)}{\mathrm{V} \times_{\varepsilon \beta}}
\end{gathered}
$$

where $\mathrm{A}_{\alpha / \beta}$ is the gross alpha/beta activity concentration of the sample $\left(\mathrm{Bq} \mathrm{L}^{-1}\right) ; \mathrm{V}$ is the volume of the sample $(\mathrm{L})$; $\varepsilon_{\alpha}$ and $\varepsilon_{\beta}$ are the alpha and beta efficiencies, respectively; $\mathrm{f}_{\mathrm{a} \alpha}$ is the alpha self-absorption factor; the self-absorption of beta phenomena was negligible $\left(\mathrm{f}_{\mathrm{a} \beta}=1\right) ; \mathrm{r}_{\mathrm{g} \alpha}$ and $\mathrm{r}_{\mathrm{g} \beta}$ are the gross count rates from the alpha and beta windows, respectively (cps); $\mathrm{r}_{0 \alpha}$ and $\mathrm{r}_{03}$ is the background count rate from the alpha and beta windows, respectively (cps); and $x$ is the crosstalk alpha-beta factor.

The minimum detectable concentration (MDC) for the gross alpha and gross beta activity concentration are calculated as follows ${ }^{22,23}$ :

$$
\operatorname{MDC}_{\alpha / \beta}\left(\mathrm{Bq} \mathrm{L}^{-1}\right)=\frac{2 \mathrm{c}_{\alpha / \beta}^{*}+\left(\mathrm{k}^{2} \mathrm{w}_{\alpha / \beta} / \mathrm{t}_{\mathrm{g}}\right)}{1-\mathrm{k}^{2} \mathrm{u}_{\mathrm{rel}}^{2}\left(\mathrm{w}_{\alpha / \beta}\right)}
$$

where $c^{*}$ is the decision threshold for the gross alpha and gross beta; $k=1.65 ; t_{g}$ is the sample counting time; $u_{\text {rel }}$ is the relative standard uncertainty; and $\mathrm{w}_{\alpha}=\frac{1}{\mathrm{~V} \times \mathrm{f}_{\mathrm{a} \alpha} \times \varepsilon_{\alpha}}$ and $\mathrm{w}_{\beta}=\frac{1}{\mathrm{~V} \times \varepsilon_{\beta}}$.

Estimation of the annual effective dose. The annual effective dose (AED) for the gross alpha and gross beta activity concentrations associated with radiation exposure through ingestion of the groundwater samples was estimated to assess health risks to adult members of the public using the following equation ${ }^{3}$ : 


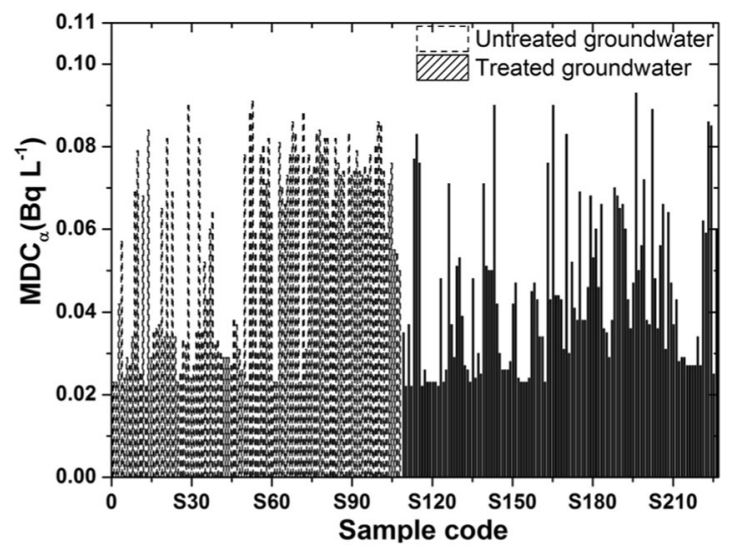

Figure 1. The minimum detectable concentration of gross alpha.

$$
\mathrm{AED}_{\alpha / \beta}\left(\mathrm{mSv} \mathrm{y}^{-1}\right)=\mathrm{A}_{\alpha / \beta} \times \mathrm{IR}_{\mathrm{w}} \times \mathrm{CF}
$$

where $\mathrm{A}_{\alpha / 3}$ is the gross alpha/beta activity concentration of the sample $\left(\mathrm{Bq} \mathrm{L}^{-1}\right)$; $\mathrm{CF}$ is the age-dependent effective dose conversion factor; and $\mathrm{IR}_{\mathrm{w}}$ is the annual ingested volume of drinking water per year. In this work, $\mathrm{IR}_{\mathrm{w}}$ $=730 \mathrm{Ly}^{-1}$ according to WHO and $\mathrm{IAEA}^{3,4}$ for an adult person and $\mathrm{CF}^{24}$ values for the main radionuclides was $\mathrm{CF}_{\mathrm{Po}-210}=1.2 \times 10^{-3} \mathrm{mSv} \mathrm{Bq}^{-1}, \mathrm{CF}_{\mathrm{Ra}-226}=2.8 \times 10^{-4} \mathrm{mSvBq}^{-1}, \mathrm{CF}_{\mathrm{Pb}-210}=6.9 \times 10^{-4} \mathrm{mSv} \mathrm{Bq}^{-1}$, and $\mathrm{CF}_{\mathrm{Ra}-228}=$ $6.9 \times 10^{-4} \mathrm{mSvBq}^{-1}$.

The radiological criteria for groundwater quality were determined by the Ministry of Natural Resources \& Environment and Ministry of Health published in the Vietnam National Technical Regulation. Moreover, the maximum admitted activity concentrations are $0.1 \mathrm{BqL}^{-1}$ for the gross alpha and $1 \mathrm{BqL}^{-1}$ for the gross beta ${ }^{1,2}$. These values are $0.5 \mathrm{BqL}^{-1}$ for the gross alpha activity concentration and $1 \mathrm{BqL}^{-1}$ for the gross beta activity concentration according to $\mathrm{WHO}$ and $\mathrm{IAEA}^{3,4}$. However, the annual effective dose value is equal to the WHO and IAEA recommended reference value $\mathrm{e}^{3,4}$ of $0.1 \mathrm{mSvy}^{-1}$.

\section{Results and discussions}

Validation of analytical procedure. Validation tests for the analytical procedure were carefully prepared by adding the spiked SRM-NIST $4322 \mathrm{C}(\mathrm{Am}-241)$ in water in the range of $0.05 \mathrm{~Bq} \mathrm{~L}^{-1}$ to $1.0 \mathrm{BqL}^{-1}$ for determination of the gross alpha and by adding the spiked NIST 4239 (Sr-90/Y-90) in water in the range of $0.5 \mathrm{BqL}^{-1}$ to $8.0 \mathrm{BqL}^{-1}$ for determination of the gross beta. The solutions were prepared according to the same sample analysis preparation procedure and counted by WPC-1050. For the gross alpha, the obtained recoveries, relative standard deviation and linearity between the measured and expected activity were from $94-98 \%$, less than $7.5 \%$ and $\mathrm{y}_{\alpha}=$ $0.9593 \mathrm{x}_{\alpha}+0.005\left(\mathrm{R}^{2}=0.9995 ; \mathrm{p}<0.001\right)$, respectively. Similarly, for the gross beta determination, the obtained recoveries were $86-94 \%$, the relative standard deviation was $3.2 \%$, and the linearity was $\mathrm{y}_{\beta}=0.9871 \mathrm{x}_{\beta}-0.0724$ $\left(\mathrm{R}^{2}=0.9996 ; \mathrm{p}<0.001\right)$.

The minimum detectable concentrations (MDCs) of gross alpha and gross beta were calculated in Eq. (3). The highest MDC values of gross alpha were inconsistent and ranged from $0.022-0.091 \mathrm{~Bq} \mathrm{~L}^{-1}$ with average values of $0.057 \mathrm{~Bq} \mathrm{~L}^{-1}$ for the untreated groundwater and ranged from $0.022-0.093 \mathrm{~Bq} \mathrm{~L}^{-1}$ with average values of $0.044 \mathrm{BqL}^{-1}$ for the treated groundwater (Fig. 1).

In contrast, the MDC of the gross beta was relatively constant for the untreated groundwater in the range $0.023-0.081 \mathrm{~Bq} \mathrm{~L}^{-1}$ with average values of $0.034 \mathrm{~Bq} \mathrm{~L}^{-1}$ and for the treated groundwater in the range $0.027-$ $0.042 \mathrm{~Bq} \mathrm{~L}^{-1}$ with average values of $0.033 \mathrm{BqL}^{-1}$ (Fig. 2).

The $\mathrm{p}$-values of the mean comparison tests ( $\mathrm{t}$-tests) show that the difference is significant $(\mathrm{p}<0.05)$ between the MDCs of the untreated and treated groundwater samples. The mean MDC value of the untreated groundwater samples is higher than that of the treated groundwater samples by approximately 1.2 times for gross alpha and 1.1 times for gross beta.

Determination of gross alpha and beta activity concentrations. In the untreated groundwater samples, for 34 samples of the 108 analyzed samples, the overall gross alpha activity is higher than the $\mathrm{MDC}_{\alpha}$; for 57 samples of the 108 analyzed samples, the gross beta activity is higher than the $\mathrm{MDC}_{\beta} ; 25$ samples can be detected at both the gross alpha and gross beta activity concentrations.

In addition, in the 118 total treated groundwater samples, there are 37 samples whose overall gross alpha activities are higher than the $\mathrm{MDC}_{\alpha}$, there are 64 samples whose gross beta activity is higher than the $\mathrm{MDC}_{\beta}$; and there are 31 samples whose gross alpha and gross beta activity concentrations could be recorded.

Table 1 presents the gross alpha and gross beta activity concentrations determined in the groundwater samples for both cases in this work. The median values of gross alpha and gross beta activities in untreated groundwater samples were $0.252 \pm 0.042 \mathrm{BqL}^{-1}$ in the range of $0.026-0.748 \mathrm{BqL}^{-1}$ and $0.154 \pm 0.015 \mathrm{BqL}^{-1}$ in the range $0.036-0.519 \mathrm{~Bq} \mathrm{~L}^{-1}$, respectively. In terms of the treated groundwater, the average values for the gross alpha and gross beta activities were $0.120 \pm 0.026 \mathrm{BqL}^{-1}$ in the range $0.024-0.450 \mathrm{BqL}^{-1}$ and $0.152 \pm 0.014 \mathrm{BqL}^{-1}$ in the 


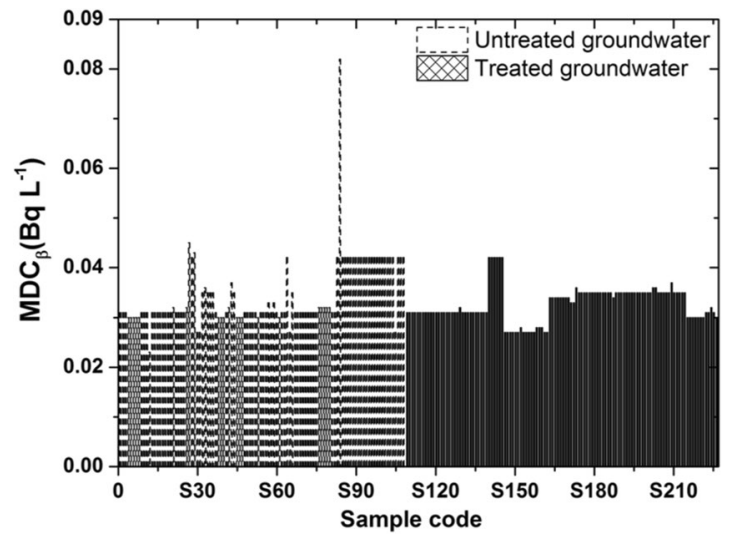

Figure 2. The minimum detectable concentration of gross beta.

range $0.027-0.632 \mathrm{BqL}^{-1}$, respectively. The $\mathrm{p}$-values of the mean comparison tests (t-tests) show that the difference between the untreated and treated groundwater samples is significant $(\mathrm{p}<0.05)$, and the mean gross alpha activity concentration for the untreated groundwater is approximately two times higher than that of the treated groundwater samples. However, the p-values of the mean gross beta activity concentration show that the similarity between untreated and treated groundwater is not significant $(p>0.05)$.

There are 19 groundwater samples whose gross alpha activity concentrations are higher than the recommended upper limit value $\mathrm{e}^{1,2}$ of $0.1 \mathrm{BqL}^{-1}$, and there are 4 samples whose gross alpha activity concentrations are higher than the recommended value of $0.5 \mathrm{~Bq} \mathrm{~L}^{-1} \mathrm{WHO}$ and IAEA ${ }^{3,4}$. After treatment processing, there are only 9 groundwater samples whose gross alpha activity concentrations are higher than the recommended value ${ }^{1,2}$, and no detectable gross alpha activity concentration is higher than the recommended upper limit value ${ }^{3,4}$; all values of gross beta activity concentrations are lower than the recommended upper limit value ${ }^{1-4}$ of $1 \mathrm{BqL}^{-1}$ for both groundwater cases, as shown in Table 1.

In this study, the gross alpha and gross beta activity concentrations were combined between the untreated and treated groundwater samples, which were $0.183 \pm 0.034 \mathrm{BqL}^{-1}$ in the range $0.024-0.748 \mathrm{BqL}^{-1}$ for the gross alpha activity concentration and $0.152 \pm 0.015 \mathrm{BqL}^{-1}$ in the range $0.027-0.632 \mathrm{~Bq} \mathrm{~L}^{-1}$ for the gross beta activity concentration. The results were compared with results obtained from samples that were collected in various regions or countries in similar studies, as shown in Table 2 . The mean gross alpha and gross beta activity concentrations were measured in the range of previously published values.

Evaluation of the annual effective dose for ingestion the groundwater samples. The origin of the gross alpha and gross beta activity concentrations was not investigated in this study. Gross alpha activity in groundwater is mainly due to uranium and its progenies, such as Po-210, Ra-226, and occasionally Th-232. The gross beta activity concentrations ${ }^{6-9}$ are probably mainly caused by $\mathrm{K}-40, \mathrm{~Pb}-210$, and $\mathrm{Ra}-228$. The 25 untreated and 31 treated groundwater samples detected both gross alpha and gross beta activities, and the results were used to calculate Pearson's correlation coefficient to estimate the relationship between emitted radionuclides of gross alpha and gross beta. The strength of the correlation is based on the guide that Evans (1996) suggested for the absolute value of $\mathrm{r}$ : $0-0.19$ corresponds to a very weak correlation, $0.20-0.39$ corresponds to a weak correlation, $0.40-0.59$ corresponds to a moderate correlation, $0.60-0.79$ corresponds to a strong correlation, and $0.80-1.0$ corresponds to a very strong correlation; a minus constitutes a negative correlation, and a plus constitutes a positive correlation ${ }^{25}$.

The results are presented in Figs. 3 and 4, and they show that Pearson's correlation coefficient between the gross alpha and gross beta for the untreated groundwater samples is 0.61 and that of the treated groundwater samples is 0.67 . The results showed that if the existing original radionuclides emitted only beta particles such as Sr-90, Y-90, Ba-133, and Cs-137 in the samples, it was difficult to obtain a strong positive correlation. Hence, it follows that among the radionuclides, the major sources of beta radiation are the uranium and thorium decay series radionuclides.

Moreover, the gross beta activity concentrations from $\mathrm{K}-40$, which is negligible because of the age-dependent effective dose conversion factor for the adult person $\left(\mathrm{CF}_{\mathrm{K}-40}=6.2 \times 10^{-6} \mathrm{mSv} \mathrm{Bq}^{-1}\right)$, are the smallest of the other radionuclides. Therefore, to calculate the annual effective dose, we considered the gross alpha activity to be due to Po-210 and Ra-226 and the gross beta activity to be due to Pb-210 and Ra-228, which were radionuclide emitters with the highest age-dependent effective dose conversion factor ${ }^{9,24}$. The annual effective doses $\left(\mathrm{mSv}^{-1}\right)$ for the adult age group in southern Vietnam due to intake of $\mathrm{Po}-210, \mathrm{Ra}-226, \mathrm{~Pb}-210$, and $\mathrm{Ra}-228$ from groundwater samples are represented in Figs. 5-8.

For the untreated samples, the annual effective doses for alpha emitters from Po-210 and Ra-226 radionuclides were calculated with ranges between $0.023-0.655 \mathrm{mSvy}^{-1}$ and $0.005-0.153 \mathrm{mSv}^{-1}$, with mean values of $0.221 \pm 0.037 \mathrm{mSvy}^{-1}$ and $0.052 \pm 0.009 \mathrm{mSvy}^{-1}$, respectively. In addition, for the treated groundwater samples, the annual effective doses for alpha emitters from Po-210 and $\mathrm{Ra}-226$ radionuclides were calculated with ranges between $0.021-0.394 \mathrm{mSvy}^{-1}$ and $0.005-0.092 \mathrm{mSvy}^{-1}$, with mean values of $0.105 \pm 0.023 \mathrm{mSvy}^{-1}$ and $0.024 \pm$ $0.005 \mathrm{mSvy}^{-1}$, respectively (Table 3). 


\begin{tabular}{|c|c|c|c|c|c|c|c|c|c|}
\hline \multicolumn{5}{|c|}{ Untreated groundwater } & \multicolumn{5}{|c|}{ Treated groundwater } \\
\hline \multirow{2}{*}{$\begin{array}{l}\text { Sample } \\
\text { code }\end{array}$} & \multicolumn{2}{|c|}{ Gross alpha } & \multicolumn{2}{|c|}{ Gross beta } & \multirow{2}{*}{$\begin{array}{l}\text { Sample } \\
\text { code }\end{array}$} & \multicolumn{2}{|c|}{ Gross alpha } & \multicolumn{2}{|c|}{ Gross beta } \\
\hline & $\mathbf{A}_{\alpha}$ & $\Delta \mathbf{A}_{\alpha}$ & $A_{\beta}$ & $\Delta \mathbf{A}_{\beta}$ & & $\mathbf{A}_{\alpha}$ & $\Delta \mathbf{A}_{\alpha}$ & $\mathbf{A}_{\beta}$ & $\Delta \mathrm{A}_{\beta}$ \\
\hline S1 & 0.060 & 0.014 & - & - & S109 & 0.083 & 0.020 & 0.099 & 0.013 \\
\hline S2 & 0.071 & 0.015 & - & - & S111 & 0.076 & 0.020 & 0.088 & 0.012 \\
\hline S8 & 0.058 & 0.016 & 0.092 & 0.012 & S113 & - & - & 0.338 & 0.020 \\
\hline S9 & - & - & 0.047 & 0.010 & S115 & - & - & 0.055 & 0.011 \\
\hline S12 & 0.403 & 0.063 & 0.234 & 0.017 & S116 & - & - & 0.067 & 0.011 \\
\hline S14 & - & - & 0.042 & 0.010 & S125 & 0.060 & 0.015 & - & - \\
\hline S15 & 0.039 & 0.013 & - & - & S128 & 0.055 & 0.015 & - & - \\
\hline S19 & 0.074 & 0.027 & - & - & S129 & 0.252 & 0.042 & 0.260 & 0.017 \\
\hline S21 & 0.521 & 0.078 & 0.344 & 0.020 & $\mathrm{~S} 130$ & 0.153 & 0.033 & 0.113 & 0.013 \\
\hline S23 & - & - & 0.118 & 0.013 & S131 & 0.065 & \begin{tabular}{|l|l|}
0.019 \\
\end{tabular} & \begin{tabular}{|l|l|} 
\\
\end{tabular} & 0.015 \\
\hline S26 & \begin{tabular}{|l|l|}
0.092 \\
\end{tabular} & \begin{tabular}{|l|l}
0.018 \\
\end{tabular} & - & - & S135 & - & - & \begin{tabular}{|l|l|}
0.100 \\
\end{tabular} & 0.012 \\
\hline S29 & \begin{tabular}{|l|l|}
0.464 \\
\end{tabular} & \begin{tabular}{|l|l|}
0.073 \\
\end{tabular} & 0.314 & 0.022 & S139 & - & - & \begin{tabular}{|l|l|}
0.058 \\
\end{tabular} & 0.011 \\
\hline S31 & \begin{tabular}{|l|}
0.029 \\
\end{tabular} & \begin{tabular}{|l|l}
0.011 \\
\end{tabular} & - & - & S144 & - & - & \begin{tabular}{|l|}
0.050 \\
\end{tabular} & 0.014 \\
\hline S32 & - & - & 0.183 & 0.016 & S146 & - & - & \begin{tabular}{|l|l|}
0.027 \\
\end{tabular} & 0.009 \\
\hline S33 & \begin{tabular}{|l|l|}
0.382 \\
\end{tabular} & \begin{tabular}{|l|l|}
0.061 \\
\end{tabular} & \begin{tabular}{|l|l|} 
\\
\end{tabular} & \begin{tabular}{|l|l|}
0.018 \\
\end{tabular} & S150 & - & - & \begin{tabular}{|l|l|}
0.088 \\
\end{tabular} & 0.011 \\
\hline S34 & \begin{tabular}{|l|l|}
0.068 \\
\end{tabular} & \begin{tabular}{|l|l|} 
\\
\end{tabular} & 0.043 & 0.012 & S151 & - & - & 0.132 & 0.013 \\
\hline S35 & \begin{tabular}{|l|l|}
0.183 \\
\end{tabular} & \begin{tabular}{|l|l|}
0.033 \\
\end{tabular} & \begin{tabular}{|l|l|} 
\\
\end{tabular} & 0.013 & S152 & 0.057 & \begin{tabular}{|l|l|}
0.013 \\
\end{tabular} & - & - \\
\hline S36 & - & - & 0.037 & 0.011 & S153 & 0.024 & \begin{tabular}{|l|l|} 
\\
\end{tabular} & - & - \\
\hline S37 & \begin{tabular}{|l|l|}
0.287 \\
\end{tabular} & \begin{tabular}{|l|l|}
0.049 \\
\end{tabular} & \begin{tabular}{|l|l|} 
\\
\end{tabular} & 0.021 & S157 & - & - & 0.277 & \begin{tabular}{|l}
0.017 \\
\end{tabular} \\
\hline S38 & - & - & 0.036 & \begin{tabular}{|l|l|}
0.010 \\
\end{tabular} & S158 & 0.092 & \begin{tabular}{|l|l|}
0.024 \\
\end{tabular} & \begin{tabular}{|l|l|}
0.200 \\
\end{tabular} & 0.015 \\
\hline S39 & - & - & \begin{tabular}{|l|l|} 
\\
\end{tabular} & \begin{tabular}{|l|l|}
0.014 \\
\end{tabular} & S159 & 0.208 & \begin{tabular}{|l|l|}
0.034 \\
\end{tabular} & \begin{tabular}{|l|l|}
0.297 \\
\end{tabular} & \begin{tabular}{|l}
0.018 \\
\end{tabular} \\
\hline S40 & - & - & \begin{tabular}{|l|l|} 
\\
\end{tabular} & \begin{tabular}{|l|l|}
0.015 \\
\end{tabular} & S160 & 0.086 & \begin{tabular}{|l|l|}
0.019 \\
\end{tabular} & 0.115 & 0.012 \\
\hline S41 & \begin{tabular}{|l|l|}
0.144 \\
\end{tabular} & 0.024 & \begin{tabular}{|l|l|}
0.069 \\
\end{tabular} & 0.012 & S161 & - & - & \begin{tabular}{|l|l|}
0.161 \\
\end{tabular} & 0.014 \\
\hline $\mathrm{S} 42$ & \begin{tabular}{|l|l|}
0.162 \\
\end{tabular} & \begin{tabular}{|l|l|}
0.026 \\
\end{tabular} & 0.051 & 0.011 & S162 & 0.034 & \begin{tabular}{|l|l|}
0.010 \\
\end{tabular} & 0.122 & \begin{tabular}{|l}
0.012 \\
\end{tabular} \\
\hline S43 & \begin{tabular}{|l|l|}
0.593 \\
\end{tabular} & \begin{tabular}{|l|l|}
0.060 \\
\end{tabular} & 0.119 & \begin{tabular}{|l|l|}
0.015 \\
\end{tabular} & S163 & - & - & \begin{tabular}{|l|l|}
0.095 \\
\end{tabular} & 0.013 \\
\hline S44 & \begin{tabular}{|l|l|}
0.493 \\
\end{tabular} & \begin{tabular}{|l|l|}
0.053 \\
\end{tabular} & 0.117 & \begin{tabular}{|l|l|}
0.014 \\
\end{tabular} & S164 & 0.082 & \begin{tabular}{|l|l|}
0.020 \\
\end{tabular} & 0.255 & 0.018 \\
\hline S46 & \begin{tabular}{|l|l|}
0.052 \\
\end{tabular} & \begin{tabular}{|l|l|}
0.017 \\
\end{tabular} & 0.178 & 0.015 & S165 & - & - & \begin{tabular}{|l|l|}
0.173 \\
\end{tabular} & 0.015 \\
\hline S47 & \begin{tabular}{|l|l|}
0.053 \\
\end{tabular} & \begin{tabular}{|l|l|}
0.017 \\
\end{tabular} & - & - & S166 & - & - & 0.124 & 0.014 \\
\hline S48 & \begin{tabular}{|l|}
0.026 \\
\end{tabular} & \begin{tabular}{|l|l}
0.010 \\
\end{tabular} & - & - & S167 & 0.070 & \begin{tabular}{|l|}
0.019 \\
\end{tabular} & \begin{tabular}{|l|l}
0.037 \\
\end{tabular} & 0.011 \\
\hline S50 & \begin{tabular}{|l|}
0.081 \\
\end{tabular} & \begin{tabular}{|l|l|}
0.031 \\
\end{tabular} & 0.084 & 0.012 & S168 & 0.083 & \begin{tabular}{|l|l|}
0.020 \\
\end{tabular} & \begin{tabular}{|l|l|}
0.144 \\
\end{tabular} & \begin{tabular}{|l}
0.014 \\
\end{tabular} \\
\hline S52 & - & - & 0.374 & \begin{tabular}{|l|l|}
0.020 \\
\end{tabular} & S170 & - & - & \begin{tabular}{|l|l|}
0.106 \\
\end{tabular} & 0.013 \\
\hline S54 & \begin{tabular}{|l|l|}
0.097 \\
\end{tabular} & \begin{tabular}{|l|l|}
0.028 \\
\end{tabular} & 0.204 & 0.015 & S172 & & & \begin{tabular}{|l|l|}
0.153 \\
\end{tabular} & 0.014 \\
\hline S57 & \begin{tabular}{|l|l|}
0.748 \\
\end{tabular} & \begin{tabular}{|l|l|}
0.097 \\
\end{tabular} & 0.393 & 0.021 & S173 & 0.264 & \begin{tabular}{|l|l|}
0.036 \\
\end{tabular} & - & - \\
\hline S59 & \begin{tabular}{|l|l|}
0.722 \\
\end{tabular} & \begin{tabular}{|l|l|}
0.095 \\
\end{tabular} & 0.519 & 0.025 & S174 & 0.045 & \begin{tabular}{|l|l|}
0.015 \\
\end{tabular} & \begin{tabular}{|l|l|}
0.058 \\
\end{tabular} & 0.012 \\
\hline S60 & \begin{tabular}{|l|l|}
0.266 \\
\end{tabular} & \begin{tabular}{|l|l}
0.048 \\
\end{tabular} & 0.296 & \begin{tabular}{|l|l|}
0.019 \\
\end{tabular} & S175 & - & - & 0.155 & 0.015 \\
\hline S63 & - & - & 0.111 & \begin{tabular}{|l|l|}
0.013 \\
\end{tabular} & S176 & 0.039 & 0.018 & \begin{tabular}{|l|l|}
0.041 \\
\end{tabular} & 0.011 \\
\hline S64 & - & - & 0.053 & \begin{tabular}{|l|l|} 
\\
\end{tabular} & S177 & 0.088 & \begin{tabular}{|l|l|}
0.020 \\
\end{tabular} & \begin{tabular}{|l}
0.058 \\
\end{tabular} & \begin{tabular}{|l|l|}
0.012 \\
\end{tabular} \\
\hline S66 & - & - & \begin{tabular}{|l|l|}
0.058 \\
\end{tabular} & \begin{tabular}{|l|}
0.012 \\
\end{tabular} & S178 & - & - & \begin{tabular}{|l|l|}
0.143 \\
\end{tabular} & 0.015 \\
\hline S69 & \begin{tabular}{|l|l|}
0.086 \\
\end{tabular} & 0.033 & 0.057 & 0.011 & S180 & - & - & \begin{tabular}{|l|l|}
0.103 \\
\end{tabular} & 0.013 \\
\hline S76 & \begin{tabular}{|l|l|}
0.366 \\
\end{tabular} & \begin{tabular}{|l|l|}
0.062 \\
\end{tabular} & 0.228 & 0.016 & S181 & 0.082 & \begin{tabular}{|l|}
0.025 \\
\end{tabular} & 0.252 & 0.018 \\
\hline S77 & \begin{tabular}{|l|l|}
0.462 \\
\end{tabular} & \begin{tabular}{|l|l|}
0.073 \\
\end{tabular} & \begin{tabular}{|l|l|} 
\\
\end{tabular} & \begin{tabular}{|l|}
0.021 \\
\end{tabular} & S182 & 0.055 & \begin{tabular}{|l|l|}
0.018 \\
\end{tabular} & 0.203 & 0.017 \\
\hline S78 & \begin{tabular}{|l|}
0.420 \\
\end{tabular} & \begin{tabular}{|l|}
0.070 \\
\end{tabular} & 0.155 & 0.014 & S183 & - & - & 0.106 & 0.014 \\
\hline S79 & \begin{tabular}{|l|}
0.388 \\
\end{tabular} & \begin{tabular}{|l|}
0.065 \\
\end{tabular} & 0.176 & 0.015 & S188 & - & - & 0.134 & 0.014 \\
\hline $\mathrm{S} 80$ & \begin{tabular}{|l|}
0.457 \\
\end{tabular} & \begin{tabular}{|l|}
0.072 \\
\end{tabular} & 0.157 & 0.014 & S189 & - & - & 0.129 & 0.014 \\
\hline S81 & \begin{tabular}{|l|}
0.162 \\
\end{tabular} & 0.043 & 0.210 & 0.016 & S190 & - & - & \begin{tabular}{|l|l|}
0.144 \\
\end{tabular} & 0.015 \\
\hline S82 & \begin{tabular}{|l|}
0.070 \\
\end{tabular} & 0.025 & - & - & S191 & - & - & 0.156 & 0.015 \\
\hline S83 & - & - & 0.046 & 0.016 & S192 & 0.092 & 0.026 & 0.331 & 0.020 \\
\hline S84 & - & - & 0.194 & 0.018 & S193 & 0.059 & 0.018 & 0.134 & 0.014 \\
\hline S85 & - & - & 0.210 & 0.018 & S194 & - & - & 0.130 & 0.014 \\
\hline S86 & - & - & 0.224 & 0.019 & S195 & 0.088 & 0.022 & 0.190 & 0.016 \\
\hline S87 & - & - & 0.215 & 0.019 & S196 & 0.333 & 0.060 & 0.349 & 0.021 \\
\hline S88 & - & - & 0.201 & 0.018 & S197 & - & - & 0.234 & 0.017 \\
\hline S89 & - & - & 0.183 & \begin{tabular}{|l|l|}
0.018 \\
\end{tabular} & S198 & 0.066 & 0.022 & 0.246 & 0.018 \\
\hline S90 & - & - & 0.070 & 0.014 & S199 & 0.092 & \begin{tabular}{|l|}
0.029 \\
\end{tabular} & 0.206 & 0.017 \\
\hline S91 & - & - & 0.061 & 0.014 & S200 & 0.040 & 0.015 & 0.071 & 0.012 \\
\hline \multicolumn{10}{|l|}{ Contin } \\
\hline
\end{tabular}




\begin{tabular}{|c|c|c|c|c|c|c|c|c|c|}
\hline \multicolumn{5}{|c|}{ Untreated groundwater } & \multicolumn{5}{|c|}{ Treated groundwater } \\
\hline \multirow{2}{*}{$\begin{array}{l}\text { Sample } \\
\text { code }\end{array}$} & \multicolumn{2}{|c|}{ Gross alpha } & \multicolumn{2}{|c|}{ Gross beta } & \multirow{2}{*}{$\begin{array}{l}\text { Sample } \\
\text { code }\end{array}$} & \multicolumn{2}{|c|}{ Gross alpha } & \multicolumn{2}{|c|}{ Gross beta } \\
\hline & $\mathbf{A}_{\alpha}$ & $\Delta \mathbf{A}_{\alpha}$ & $\mathbf{A}_{\beta}$ & $\Delta \mathrm{A}_{\beta}$ & & $\mathbf{A}_{\alpha}$ & $\Delta \mathrm{A}_{\alpha}$ & $\mathbf{A}_{\beta}$ & $\Delta \mathrm{A}_{\beta}$ \\
\hline S92 & - & - & 0.045 & 0.014 & S202 & 0.450 & 0.069 & 0.632 & 0.029 \\
\hline S93 & - & - & 0.048 & 0.014 & S203 & 0.205 & 0.034 & 0.093 & 0.013 \\
\hline S94 & - & - & 0.043 & 0.013 & S204 & 0.037 & 0.014 & - & - \\
\hline S96 & - & - & 0.057 & 0.014 & S205 & 0.223 & 0.038 & 0.254 & 0.018 \\
\hline S97 & - & - & 0.057 & 0.014 & S206 & - & - & 0.127 & 0.014 \\
\hline S98 & - & - & 0.076 & 0.014 & S208 & 0.087 & 0.027 & 0.139 & 0.015 \\
\hline S99 & - & - & 0.076 & 0.014 & S209 & 0.220 & 0.035 & 0.186 & 0.016 \\
\hline S100 & - & - & 0.055 & 0.014 & S210 & 0.060 & 0.017 & 0.052 & 0.012 \\
\hline S101 & - & - & 0.051 & 0.014 & S211 & - & - & 0.044 & 0.011 \\
\hline S104 & - & - & 0.089 & 0.015 & S218 & - & - & 0.032 & 0.010 \\
\hline \multirow[t]{5}{*}{ S108 } & - & - & 0.070 & 0.014 & S221 & - & - & 0.103 & 0.013 \\
\hline & & & & & S222 & - & - & 0.036 & 0.010 \\
\hline & & & & & S223 & - & - & 0.183 & 0.015 \\
\hline & & & & & S224 & 0.318 & 0.061 & 0.324 & 0.019 \\
\hline & & & & & S226 & - & - & 0.051 & 0.011 \\
\hline Mean & 0.252 & 0.042 & 0.154 & 0.015 & Mean & 0.120 & 0.026 & 0.152 & 0.014 \\
\hline *Range & \multicolumn{2}{|c|}{$0.026-0.748$} & \multicolumn{2}{|c|}{$0.036-0.519$} & *Range & \multicolumn{2}{|c|}{$0.024-0.450$} & \multicolumn{2}{|c|}{$0.027-0.632$} \\
\hline
\end{tabular}

Table 1. Gross alpha and gross beta activity concentrations of the groundwater samples with uncertainties for both cases. *Range: min - max. - : not detectable.

\begin{tabular}{|c|c|c|c|c|c|}
\hline \multirow[b]{2}{*}{ Region/Country } & \multicolumn{2}{|c|}{$A_{\alpha}\left(B q L^{-1}\right)$} & \multicolumn{2}{|c|}{$\mathrm{A}_{\beta}\left(\mathrm{Bq} \mathrm{L}^{-1}\right)$} & \multirow[b]{2}{*}{ References } \\
\hline & Mean & Range & Mean & Range & \\
\hline Albania & - & $0.01-0.126$ & - & $0.029-0.884$ & $\mathrm{Cfarku}^{8}$ et al. \\
\hline Balaton/Hungary & 0.189 & $0.035-1.749$ & 0.209 & $0.033-2.105$ & Jobbágy $^{7}$ et al. \\
\hline Galati/Romania & 0.022 & $<0.06-0.852$ & 0.076 & $<0.025-0.435$ & Pintilie $^{9}$ et al. \\
\hline Hail/Saudi Arabia & 2.150 & $0.170-5.140$ & 2.600 & $0.480-5.160$ & $\begin{array}{l}\text { Shabana and } \\
\text { Kinsara }^{26}\end{array}$ \\
\hline Italy & - & $<0.008-0.186$ & - & $<0.048-0.150$ & Forte $^{27}$ et al. \\
\hline Katsina/Nigeria & - & $0.080-2.300$ & - & $0.120-4.970$ & $\begin{array}{l}\text { Muhammad } \\
\text { et al. }\end{array}$ \\
\hline Nevsehir/Turkey & 0.192 & $0.080-0.380$ & 0.579 & $0.120-3.470$ & Turhan ${ }^{19}$ et al. \\
\hline $\begin{array}{l}\text { Sao Paulo and Minas } \\
\text { Gerais States/Brazil }\end{array}$ & - & $0.001-0.428$ & - & $0.120-0.860$ & Bonotto $^{6}$ et al. \\
\hline Sebia & - & $0.001-0.013$ & - & $0.041-0.173$ & Janković ${ }^{29}$ et al. \\
\hline Southern/Vietnam & 0.183 & $0.024-0.748$ & 0.152 & $0.027-0.632$ & Present study \\
\hline
\end{tabular}

Table 2. Gross alpha and gross beta activity concentrations in some regions or countries.

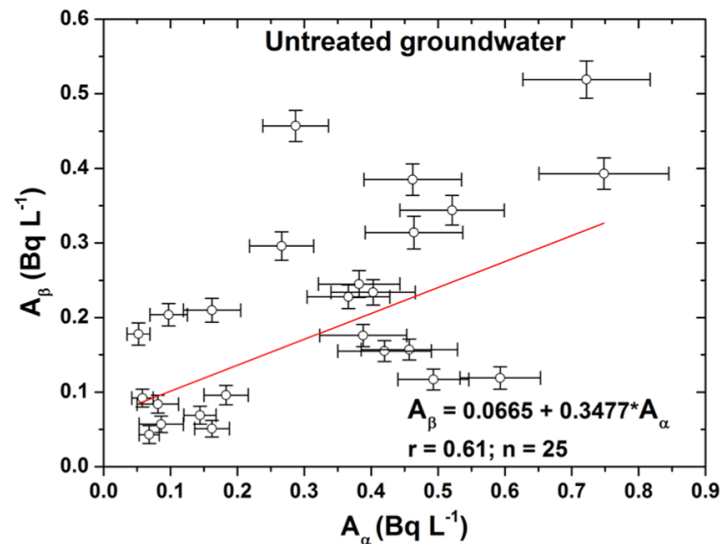

Figure 3. The correlation function of the gross alpha and gross beta activity concentrations for the untreated groundwater samples. 


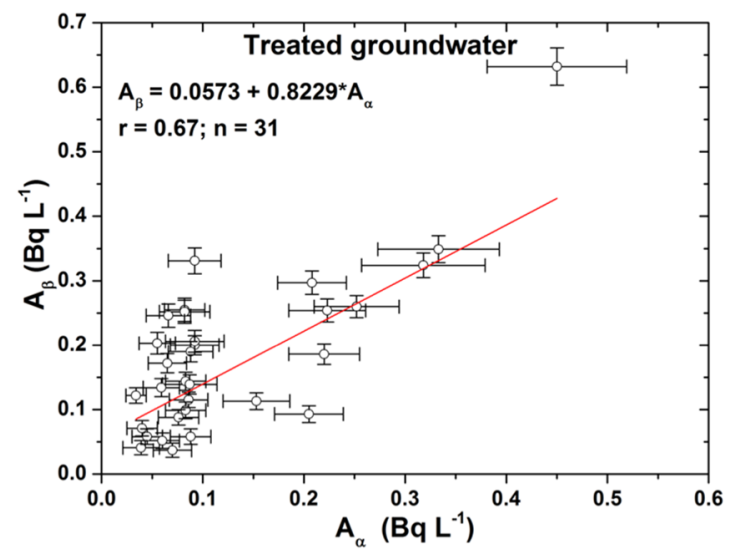

Figure 4. The correlation function of the gross alpha and gross beta activity concentrations for the treated groundwater samples.

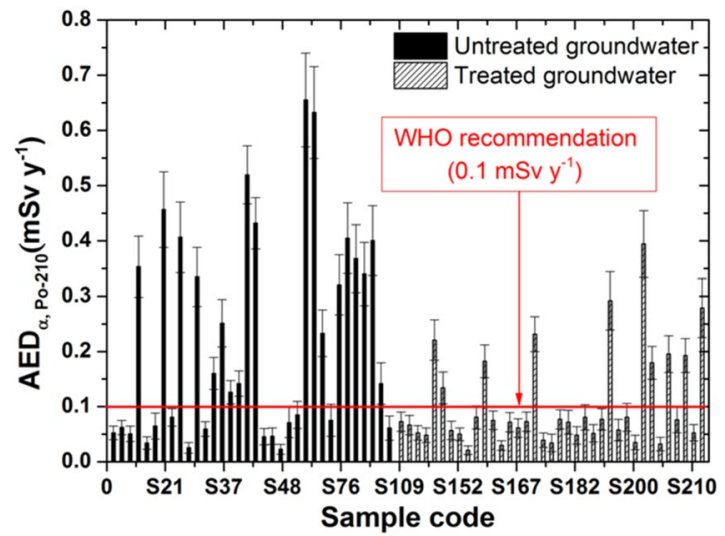

Figure 5. The annual effective dose due to intake of Po-210 in the groundwater samples.

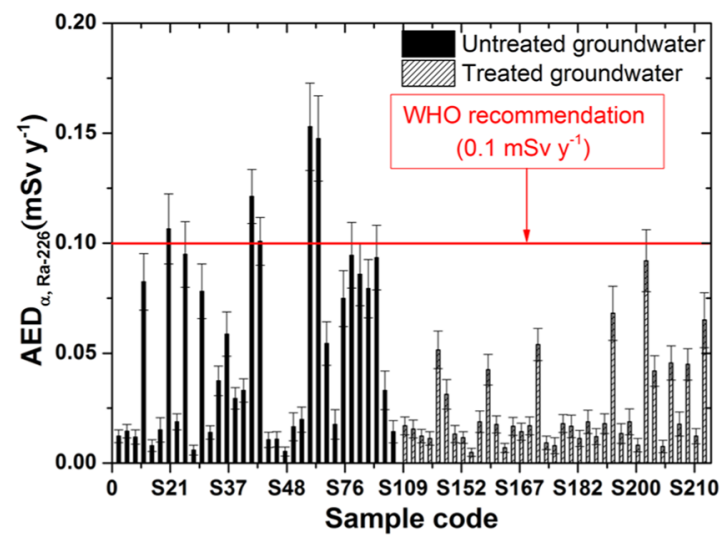

Figure 6. The annual effective dose due to intake of Ra-226 in the groundwater samples.

For the untreated samples, Figs. 5, 6 show that the annual effective doses of 19 samples for Po-210 and 5 samples for Ra-226 are higher than the recommended $0.1 \mathrm{mSv}^{-1}$ by WHO and IAEA ${ }^{3,4}$. However, for the treated groundwater samples, the annual effective dose results are reduced in up to 10 samples for Po-210 and are not detectable in samples for Ra-226. Moreover, for the untreated samples, the mean value of the annual effective dose of the Po-210 radionuclide is 2 times higher and up to 6.5 times than that of the reference value, which is the highest for one adult person. Fortunately, the results are reduced by a factor of two for both radionuclides, which means that the treatment process is effective in removing the original radionuclides, which emit alpha particles. 


\begin{tabular}{|l|l|l|l|l|}
\hline \multirow{2}{*}{ Radionuclides } & \multicolumn{3}{|l|}{ Untreated groundwater $\left(\mathbf{m S v ~}^{-1}\right)$} & \multicolumn{2}{l|}{ Treated groundwater $\left(\mathbf{m S v ~}^{-1}\right)$} \\
\cline { 2 - 5 } & Mean & Range & Mean & Range \\
\hline Po-210 & $0.221 \pm 0.037$ & $0.023-0.655$ & $0.105 \pm 0.023$ & $0.021-0.394$ \\
\hline Ra-226 & $0.053 \pm 0.009$ & $0.005-0.153$ & $0.024 \pm 0.005$ & $0.005-0.092$ \\
\hline Pb-210 & $0.077 \pm 0.008$ & $0.018-0.261$ & $0.077 \pm 0.007$ & $0.014-0.318$ \\
\hline Ra-228 & $0.077 \pm 0.008$ & $0.018-0.261$ & $0.077 \pm 0.007$ & $0.014-0.318$ \\
\hline WHO and IAEA ${ }^{3,4}$ & 0.1 & \multicolumn{4}{|l}{} \\
\hline
\end{tabular}

Table 3. The annual effective dose for some radionuclides through ingestion of the groundwater samples.

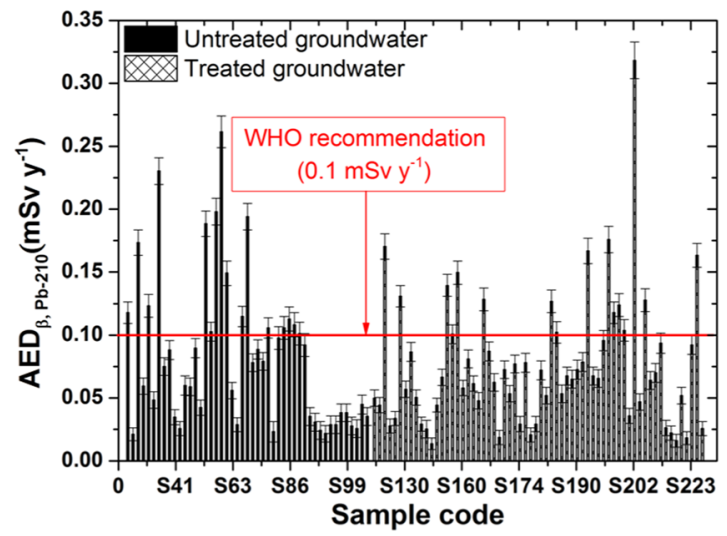

Figure 7. The annual effective dose due to intake of $\mathrm{Pb}-210$ in the groundwater samples.

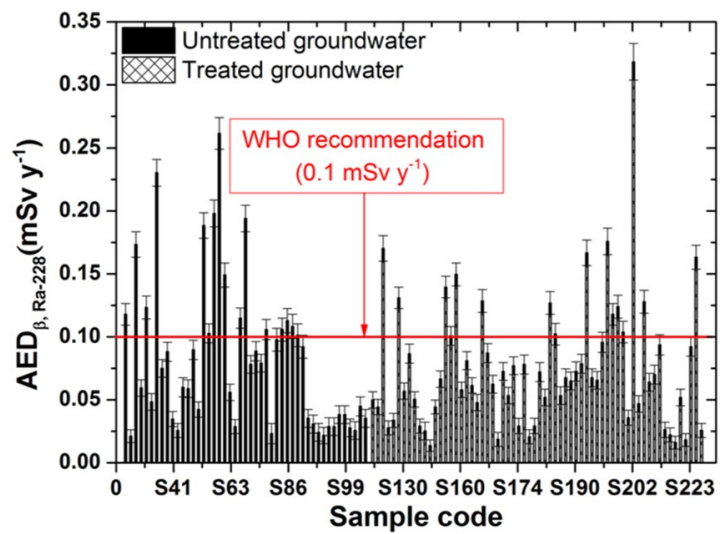

Figure 8. The annual effective dose due to intake of Ra-228 in the groundwater samples.

Because the age-dependent effective dose conversion factors for $\mathrm{Pb}-210$ and $\mathrm{Ra}-228$ are equal, the results for both radionuclides are the same and are represented in Figs. 7, 8. The annual effective doses are calculated with ranges between $0.018-0.261 \mathrm{mSvy}^{-1}$ and $0.014-0.318 \mathrm{mSvy}^{-1}$, with mean values of $0.077 \pm 0.008 \mathrm{mSvy}^{-1}$ and $0.077 \pm 0.007 \mathrm{mSvy}^{-1}$ for the untreated and treated groundwater samples, respectively. The results in this work are lower than the recommended values by WHO and $\mathrm{IAEA}^{3,4}$ for both radionuclides.

\section{Conclusions}

In the present work, the annual effective dose of the groundwater samples was evaluated to assess its compliance with national and international regulations. Therefore, this work can be used as a baseline for ascertaining possible changes in environmental radioactivity due to industrial and other human activities. The gross alpha and gross beta activity concentrations were determined for 108 untreated groundwater and 118 treated groundwater samples, which were collected in southern Vietnam.

In most cases, the gross alpha and gross beta activity concentrations were below the recommended values. The results were combined between the two kinds of groundwater samples to allow for comparisons with various regions or countries in similar studies, and the results show that the mean gross alpha and gross beta activity concentrations were measured in the acceptable range. 
The annual effective dose was based on the assumption that major contributions of radionuclides were evaluated due to the ingestion of drinking water. The annual effective doses for $\mathrm{Pb}-210, \mathrm{Ra}-226$, and $\mathrm{Ra}-228$ radionuclides are lower than those recommended reference values established by WHO and IAEA, except for Po-210.

Further investigation is required to estimate the annual effective dose due to the alpha- and beta-emitting radionuclides in the water samples. It is necessary to determine the specific activity of all radionuclides in the samples with the highest age-dependent effective dose conversion factor; in addition, the annual effective dose does not exceed $0.1 \mathrm{mSvy}^{-1}$.

Received: 22 May 2019; Accepted: 24 February 2020;

Published online: 09 March 2020

\section{References}

1. QCVN 09-MT:2015/BTNMT. National technical regulation on groundwater quality, Ministry of Natural Resources and Environment (in Vietnamese) (2015).

2. QCVN 01-1:2018/BYT. National technical regulation on domestic water quality, Ministry of Health (in Vietnamese) (2018).

3. WHO. Guidelines for drinking-water quality 4ed Ch. 9, 203-218, WHO publications, Geneva (2017).

4. IAEA. Criteria for radionuclide activity concentrations for food and drinking water, 10-25 (2016).

5. UNSCEAR. Sources and Effects of Ionizing Radiation, 35-36. United Nation Publication, New York (2000).

6. Bonotto, D. M., Bueno, T. O., Tessari, B. M. \& Silva, A. The natural radioactivity in water by gross alpha and beta measurements. Radiation Measurements 44, 92-101 (2009).

7. Jobbágy, V., Kávási, N., Somlai, J., Dombovári, P., Gyöngyösi, G. \& Kovács, T. Gross alpha and beta activity concentrations in spring waters in Balaton Upland, Hungary. Radiation Measurements 46, 195-163 (2011).

8. Cfarku, F. et al. A preliminary study of gross alpha/beta activity concentrations in drinking waters from Albania. Journal of Radioanalytical and Nuclear Chemistry 301, 435-442 (2014).

9. Pintilie, V., Ene, A., Georgescu, L. P., Morar, L. \& Iticescu, C. Measurements of gross alpha and beta activity in drinking water from Galati region, Romania. Romanian Reports in Physics 68(3), 1208-1220 (2016).

10. Jia, G., Torri, G., Innocenzi, P., Ocone, R. \& Lullo, A. Di. Determination of radium isotopes in mineral and environmental water samples by alpha-spectrometry. Journal of Radioanalytical and Nuclear Chemistry 267, 505-514 (2006).

11. Rožmarić, M., Rogić, M., Benedik, L. \& Štrok, M. Natural radionuclides in bottled drinking waters produced in Croatia and their contribution to radiation dose. Science of the Total Environment 437, 53-60 (2012).

12. Medley, P., Martin, P., Bollhöfer, A. \& Parry, D. ${ }^{226} \mathrm{Ra}$ and ${ }^{228} \mathrm{Ra}$ measurement on a $\mathrm{BaSO}_{4}$ co-precipitation source. Applied Radiation and Isotopes 95, 200-207 (2015).

13. Al-Hamarneh, I. F. \& Almasoud, F. I. A Comparative Study of Different Radiometric Methodologies for the Determination of ${ }^{226} \mathrm{Ra}$ in Water. Nuclear Engineering and Technology 50, 159-164 (2018).

14. Parsa, B., Obed, R. N., Nemeth, W. K. \& Suozzo, G. Concurrent determination of ${ }^{224} \mathrm{Ra},{ }^{226} \mathrm{Ra},{ }^{228} \mathrm{Ra}$, and unsupported ${ }^{212} \mathrm{~Pb}$ in a single analysis for drinking water and wastewater: Dissolved and suspended fractions. Health Physics 86, 145-149 (2004).

15. Condomines, M., Rihs, S., Lloret, E. \& Seidel, J. L. Determination of the four natural Ra isotopes in thermal waters by gamma-ray spectrometry. Applied Radiation and Isotopes 68, 384-391 (2010).

16. Diab, H. M. \& Abdellah, W. M. Validation of ${ }^{226} \mathrm{Ra}$ and ${ }^{228} \mathrm{Ra}$ measurements in water samples using gamma spectrometric analysis. Journal of Water Resource and Protection 5, 53-57 (2013).

17. IAEA. A procedure for the rapid determination of Ra-226 and Ra-228 in drinking water by liquid scintillation counting, 7-12 (2014).

18. Forte, M. et al. Validation of a method for measuring ${ }^{226} \mathrm{Ra}$ in drinking waters by LSC. Applied Radiation and Isotopes 103, 143-150 (2015).

19. Turhan, S., Ozcitak, E., Taskın, H. \& Varinlioglu, A. Determination of natural radioactivity by gross alpha and beta measurements in groundwater samples. Water Research. 47, 3103-3108 (2013).

20. Sarvajayakesavalu, S. et al. Geographic information system mapping of gross alpha/beta activityconcentrations in ground water samples from Karnataka, India. A preliminary study, Groundwater for Sustainable Development 6, 164-168 (2018).

21. General Statistics Office. Statistical summary book of Vietnam 2017. Statistical Publishing House, Hanoi, 79-80 (In Vietnamese) (2017).

22. ISO. Water quality - Measurement of gross alpha and gross beta activity in non-saline water - Thin source deposit method. ISO 10704:2009, 3-12 (2009).

23. IAEA. Determination and interpretation of characteristic limits for radioactivity measurements, 22-28 (2017).

24. ICRP. Compendium of dose coefficients based on ICRP publication 60 (eds Clement, C. H. et al.), 51-53. ICRP Publication 119. Ann. ICRP 41(Suppl.) (2012).

25. Beldjazia, A. \& Alatou, D. Precipitation variability on the massif Forest of Mahouna (North Eastern-Algeria) from 1986 to 2010. International Journal of Management and Business Research 5, 2226-8235 (2016).

26. Shabana, E. I. \& Kinsara, A. A. Radioactivity in groundwater of high Background radiation area. Journal of Environmental Radioactivity 137, 181-189 (2014).

27. Forte, M., Rusconi, R., Cazzaniga, M. T. \& Sgorbati, G. The measurement of radioactivity in Italian drinking waters. Microchemical Journal 85, 98-102 (2007).

28. Muhammad, B. G., Jaafar, M. S. \& Akpa, T. A survey of gross alpha and beta activity concentrations in groundwater from Katsina area of Northern Nigeria. Radiation Protection Dosimetry 141(2), 127-133 (2010).

29. Janković, M. M., Todorovića, D. J., Todorović, N. A. \& Nikolov, J. Natural radionuclides in drinking waters in Serbia. Applied Radiation and Isotopes 70, 2703-2710 (2012).

\section{Acknowledgements}

The authors sincerely thank their partner for assistance in collecting samples. The authors would like to express our thanks to the anonymous reviewers of this manuscript for their critical review and helpful discussions.

\section{Author contributions}

Phan Long Ho, Le Dinh Hung, and Vu Tuan Minh contributed by conducting experiments, obtaining data and writing the manuscript. Dang Van Chinh, Chau Van Tao and Tran Thien Thanh contributed significantly to the explanation of data and revision of the manuscript.

\section{Competing interests}

The authors declare no competing interests. 


\section{Additional information}

Correspondence and requests for materials should be addressed to T.T.T.

Reprints and permissions information is available at www.nature.com/reprints.

Publisher's note Springer Nature remains neutral with regard to jurisdictional claims in published maps and institutional affiliations.

(c) (i) Open Access This article is licensed under a Creative Commons Attribution 4.0 International License, which permits use, sharing, adaptation, distribution and reproduction in any medium or format, as long as you give appropriate credit to the original author(s) and the source, provide a link to the Creative Commons license, and indicate if changes were made. The images or other third party material in this article are included in the article's Creative Commons license, unless indicated otherwise in a credit line to the material. If material is not included in the article's Creative Commons license and your intended use is not permitted by statutory regulation or exceeds the permitted use, you will need to obtain permission directly from the copyright holder. To view a copy of this license, visit http://creativecommons.org/licenses/by/4.0/.

(C) The Author(s) 2020 